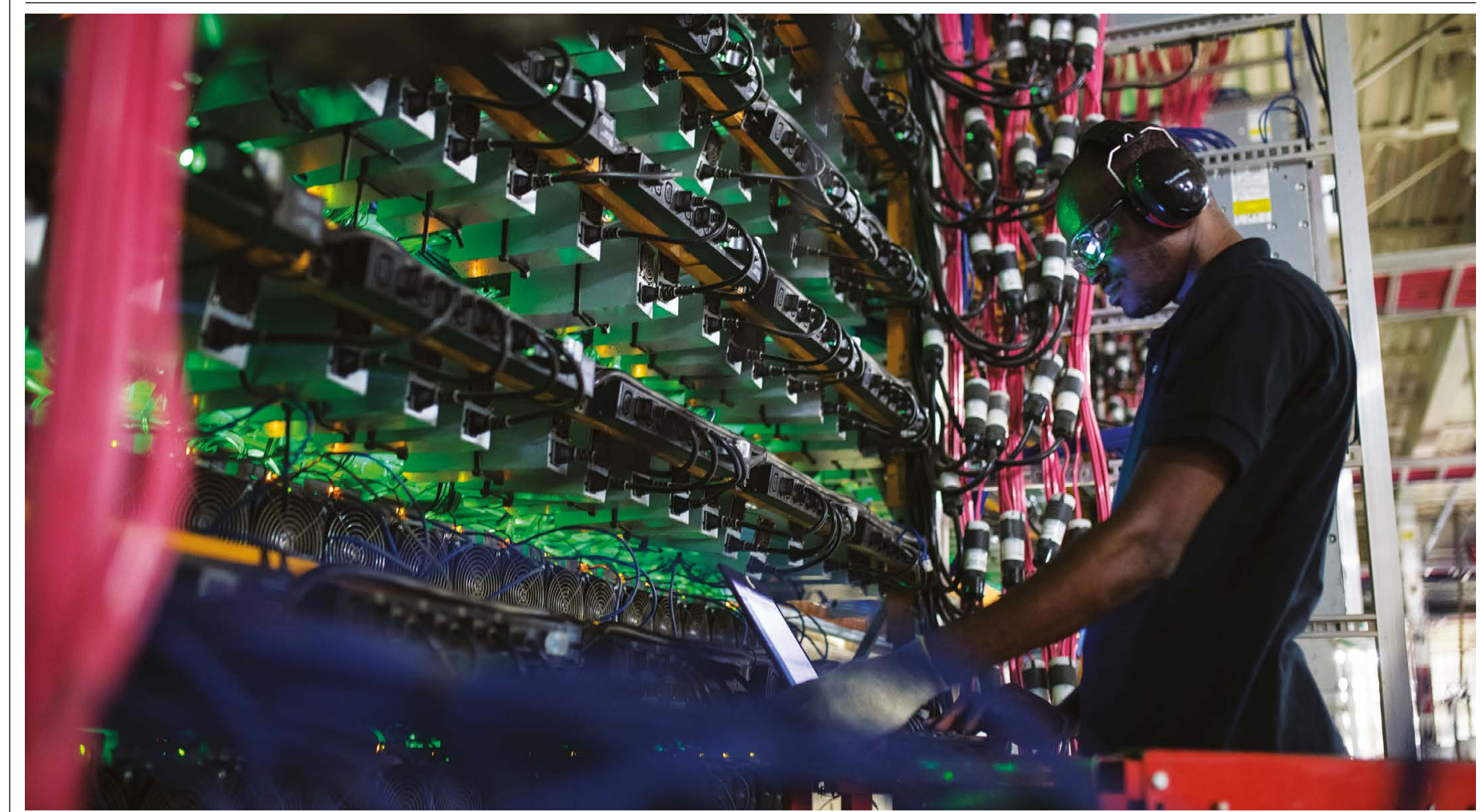

A technician monitors cryptocurrency-mining rigs at a Bitfarms facility in Saint-Hyacinthe, Canada.

\title{
The storied state of economics
}

\section{Robert Shiller's study probes how social behaviour supersedes statistics in determining the fate of economies. By Tim Jackson}

\section{4

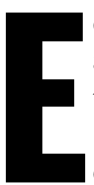
conomists are tellers of stories and makers of poems," wrote the economic historian Deidre McCloskey in 1990. It's a curious observation for a profession that prides itself on hard-nosed, quantitative analysis and strives continually for predictive power. The Nobel-prizewinning economist Robert Shiller goes even further.

Stories are more powerful than statistics, he claims. The irrationality inherent in financial exuberance (and despair) defies the neat territory of numbers and demands a deeper excursion into the decidedly unruly world of narratives. That is the declared aim of his book Narrative Economics.

It's a compelling hypothesis. Since the 1960s, we have known that science is socially constructed. Since the 1980s, sociologists have sought to understand the 'social amplification of risk' - in which people are drawn inexorably towards stories of disaster or triumph (rather than statistics or probabilities) as the lodestone for the perceptions of risk that guide their everyday decisions. Around the same time, philanthropist George Soros adapted the concept of reflexivity to explain how investors' perceptions affect the social environment, which, in turn, informs their perceptions.

This feedback loop allows speculative

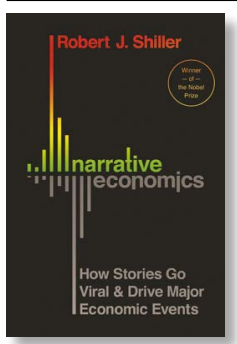

bubbles to arise with alarming speed, and then collapse again. The phenomenon reached its apotheosis in a now infamous remark from Citibank chief executive Chuck Prince that "when the music stops, in terms of liquidity, things will be complicated. But as long as the music is playing, you've got to get up and dance." His prophetic words came just months before the 2007-08 financial crisis struck.

Shiller elevates these insights into a fullblown exploration of the multiple ways in which narratives influence economic behaviour. Much as he tracked the rise and fall of asset prices in his Nobel-prizewinning work, he now charts the flux of narrative memes using Google's Ngram Viewer - which allows users to track the frequency of words and phrases in text over time - and Proquest's database of news citations. It's a quaint device, and there's a deceptive similarity between the time-series 
graphics in Narrative Economics and those in his bestselling book Irrational Exuberance (2000). But the message is effective: the value of your story might go up as well as down.

The empirical core of the book is a detailed exploration of numerous real-life case studies, ranging from bimetallism (an old-fashioned form of money) to bitcoin (a brand-new one), and from the Great Depression of the 1930 s to the Great Recession of recent years. Along the way, his anecdotes form a fascinating subscript. A convincing case is made, for instance, that fears of a 'singularity' - a point of no return arising from technological advances - are perennial. He notes numerous viral outbursts of this meme (associated with cotton mills, electricity and computers, for instance) dating back to the nineteenth century. Today's apocalyptic anxieties about a robot takeover are nothing new and should not be heeded, Shiller seems to imply. How that will turn out remains to be seen.

We learn that the mechanism through which a memorable turn of phrase goes viral can be described as a form of contagion, mirroring models from epidemiology. But we are also persuaded that viral success depends inherently on the messenger. Few remember that the phrase "the only thing we have to fear is fear itself", immortalized by US president Franklin D. Roosevelt during the Great Depression, wasfirst uttered years earlier by economist Irving Fisher. It's troubling, of course, to be reminded that the rewards for creativity are often misallocated - particularly in today's plagiaristic world of social media, with its immense powers of narrative acceleration. But for me, this particular example raised a deeper concern.

Fear is a rational response from people whose livelihoods are under existential threat. So why would a president inveigh against it? The answer is that Roosevelt was painfully aware of the implications of fear. He was addressing what the economist John Maynard Keynes (borrowing from another long-forgotten creative) called the "paradox of thrift": the tendency of ordinary people to curtail their consumption in the face of economic uncertainty, and put their money into savings instead.

Such behaviour is sensible, admirable even, at the individual level. Perhaps it is so at the planetary level, too: lower consumption might benefit the environment. But economics has a problem with it. As people spend less, demand is suppressed, prolonging the recession. The same thing happened after the $2007-08$ crisis. The paradox of thrift was the foundation for Keynes's most famous proposal: that governments provide stimulus that could return the economy to growth when people would not. This was the rationale for Roosevelt's New Deal package of reforms, and the inspiration for the proposed US legislation called the Green New Deal.

Keynes was a pragmatist; his prescriptions were a response to the diseases of the day. But he was also a visionary. In his essay 'Economic Possibilities for Our Grandchildren' (1930), he foresaw a time when our society would move beyond growth. It hasn't happened yet - in spite of economist Kenneth Boulding's remark to the US Congress in 1973 that "anyone who believes exponential growth can go on forever in a finite world is either a madman or an economist".

Shiller is clearly not a madman. But in the course of an otherwise fascinating exploration

\section{“It's troubling, of course, to be reminded that the rewards for creativity are often mislocated."}

of the power of story, he never once acknowledges that eternal growth is itself just a narrative. He notes that the logic of relentless expansion conflicts with the logic of human anxiety. But he assumes that it is people who are at fault. Narratives can have clear, moral and prudential foundations, it seems, but they might still be cast as irrational.

Indeed, for Shiller, that memorable speech on the "fear of fear" shows government attempting to "lean against false or misleading narratives and establish a moral authority against them". Roosevelt's remark was designed to "create and disseminate counternarratives that establish more rational and more public-spirited economic behavior". What Shiller seems to be saying is this: when ordinary human sentiment runs counter to the prevailing logic of capitalism, the state must override it. It is a deeply suspect, potentially dangerous conclusion. But it, too, demonstrates just how pervasive narrative is.

Ultimately, Narrative Economics is an eloquent and accessible exposition of a seductive idea. It's a particularly compelling hypothesis for Britain, a country still reeling from a public referendum whose outcome was determined by viral confabulations of the most pernicious kind. We are all "tellers of stories and makers of poems". But neither economists nor politicians can claim moral authority over narrative truth. We must all choose carefully which stories we live by.

Tim Jackson is director of the Centre for the Understanding of Sustainable Prosperity at the University of Surrey in Guildford, UK, and author of Prosperity without Growth. e-mail: t.jackson@surrey.ac.uk

\section{Testosterone chronicles: truths and tall tales}

\section{A book on the hormone dissects fact from fake and questions interpretations. By Randi Hutter Epstein}

0 n 1 June 1889, renowned neurologist Charles-Édouard Brown-Séquard shocked his colleagues. Speaking at the Paris Society of Biology, the 72-year-old announced that a slurry made from the ground testicles of guinea pigs and dogs (injected under his skin ten times in three weeks) made him stronger. He also noted that his "jet of urine" lengthened by $25 \%$.

Brown-Séquard was ridiculed by his peers throughout Europe for disseminating results with no scientific basis and promoting quack youth-enhancing 'cures'. Yet the bizarre elixir found favour with members of the public in the United States, United Kingdom and Europe - at least among men eager to recapture youthful sexual prowess. As the engaging book Testosterone explains, Brown-Séquard's testimonial helped to shape future studies that linked the hormone to alleged 'manliness'.

Anthropologist Katrina Karkazis and sociomedical scientist Rebecca Jordan-Young did not write Testosterone to rehash familiar tales of wacky hormone experiments of yore, although this is one of a few that they include. Their contention is that many testosterone researchers - then and now, and intentionally or not - interpret data with blinkers on. When the facts do not fit the paradigm, the authors argue, findings are moulded into flawed dogma. Karkazis and Jordan-Young strive to comprehend how scientific practice

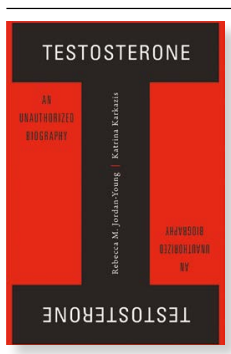

Testosterone: An Unauthorized Biography Rebecca M. Jordan-

Young, Katrina Karkazis. Harvard University Press (2019) 